\title{
Magnetic resonance imaging of persistent myocardial obstruction after myocardial infarction. A tool becoming increasingly important in clinical cardiology?
}

\author{
Leo H. B. Baur
}

Received: 11 February 2009/Accepted: 2 March 2009/Published online: 17 March 2009

(C) The Author(s) 2009. This article is published with open access at Springerlink.com

Aggressive reperfusion therapy using percutaneous coronary intervention (PCI) techniques has contributed significantly with the decrease of cardiac mortality after myocardial infarction in the last decade. This by limiting myocardial necrosis and infarct size [1]. Despite complete restoration of flow in the epicardial coronary artery after PCI, myocardial perfusion is not restored in up to $30 \%$ of patients due to microvascular obstruction [2]. Microvascular obstruction is known to be associated with a higher incidence of left ventricular remodeling, post infarct complications, congestive heart failure and death [3]. Imaging of the extent of microvascular obstruction is important because local delivery of pluripotent cells, having cardiomyogenic potential, in viable infarct borders might regenerate heart tissue [4]. The preferred way to detect microvascular obstruction with MRI is using gadolinium enhanced magnetic resonance imaging. This can be done using first-pass perfusion and with late gadolinium enhancement $[5,6]$.

After contrast injection, initially hypoenhanced regions, corresponding to areas with microvascular obstruction, are seen surrounded by a larger region of hyperenhancement. The hypoenhancement is due to

L. H. B. Baur ( $ه)$

Department of Cardiology, Atrium medical centre parkstad, University of Maastricht, Henri Dunantstreet 5, 6401CX Heerlen, the Netherlands

e-mail: 1.baur@atriummc.nl substantially reduced perfusion at the microcirculatory level, which prevents penetration of contrast into the core of the infarct. Because the flow in these regions is low, they become dark initially but become hyperenhanced later, as soon as contrast accumulates.

Acute myocardial infarction is also accompanied by myocardial edema [7]. T2-weighted (T2w) MRI is a noninvasive method to visualize myocardial edema after myocardial infarction [8]. In T2w images, there is a high signal intensity in the area of the infarction, corresponding with the amount of myocardial water $[9,10]$. Because the area of edema is larger than the true infarction size, the hyperintense area on $\mathrm{T} 2 \mathrm{w}$ images corresponds to a viable area, which is at risk [10]. The peri-infarct zone can be calculated as the size of edema on T2w MRI and the infarct size on delayed contrast enhanced MRI [8]. The current study of Choi et al. [11] in the International Journal of Cardiac Imaging shows, that in a pig pig model the extent of persistent microvascular obstruction was nearly half in a group without high signal intensity on $\mathrm{T} 2 \mathrm{w}$ imaging compared to the group with high intensity signals. The contrast ratio of $\mathrm{T} 2 \mathrm{w}$ images showed a significant inverse correlation with the extent of persistent microvascular obstruction observed in delayed enhancement images. The contrast ratio of T2-weighted image showed also a significant inverse correlation with the extent of intramyocardial hemorrhage seen in postmortem histochemical staining. In clinical practice, these findings could be used for risk stratification of patients after myocardial infarction or 
to select patients for additional treatment with injection of cells after percutaneous intervention. Further clinical studies are needed to prove the additional value of this strategy.

Open Access This article is distributed under the terms of the Creative Commons Attribution Noncommercial License which permits any noncommercial use, distribution, and reproduction in any medium, provided the original author(s) and source are credited.

\section{References}

1. Grines CL, Browne KF, Marco J, Rothbaum D, Stone GW, O' Keefe J, Overlie P, Donohue B, Chelliah N, Timmis GC et al (1993) Primary angioplasty in myocardial infarction study group. A comparison of immediate angioplasty with thrombolytic therapy for acute myocardial infarction. N Engl J Med 328:673-679

2. Kloner RA, Ganote CE, Jennings RB (1974) The "noreflow" phenomenon after temporary coronary occlusion in the dog. J Clin Invest 54:1496-1508

3. Wu KC, Zerhouni EA, Judd RM, Lugo-Olivieri CH, Barouch LA, Schulman SP, Blumenthal RS, Lima JA (1998) Prognostic significance of microvascular obstruction by magnetic resonance imaging in patients with acute myocardial infarction. Circulation 97:765-772

4. Beeres SL, Bax JJ, Kaandorp TA, Zeppenfeld K, Lamb HJ, Dibbets-Schneider P, Stokkel MP, Fibbe WE, de Roos A, van der Wall EE, Schalij MJ, Atsma DE (2006) Usefulness of intramyocardial injection of autologous bone marrowderived mononuclear cells in patients with severe angina pectoris and stress-induced myocardial ischemia. Am J Cardiol 97:1326-1331
5. Lima JA, Judd RM, Bazille A, Schulman SP, Atalar E, Zerhouni EA (1995) Regional heterogeneity of human myocardial infarcts demonstrated by contrast-enhanced MRI. Potential mechanisms. Circulation 92:1117-1125

6. Nijveldt R, Beek AM, Hofman MB, Umans VA, Algra PR, Spreeuwenberg MD, Visser CA, van Rossum AC (2007) Late gadolineum-enhanced cardiovascular magnetic resonance evaluation of infarct size and microvascular obstruction in optimally treated patients after acute myocardial infarction. J Cardiovasc Magn Reson 9:765-770

7. Jennings RB, Schaper J, Hill ML, Steenbergen C Jr, Reimer KA (1985) Effect of reperfusion late in the phase of reversible ischemic injury. Changes in cell volume, electrolytes, metabolites, and ultrastructure. Circ Res 56:262-278

8. Stork A, Lund GK, Muellerleile K, Bransmann PM, NolteErnsting C, Kemper J, Begemann PGC, Adam G (2006) Characterization of the peri-infarction zone using T2weighted MRI and delayed-enhancement MRI in patients with acute myocardial infarction. Eur Radiol 16:2350-2357

9. Lim TH, Hong MK, Lee JS, Mun CW, Park SJ, Park SW, Ryu JS, Lee JH, Chien D, Laub G (1997) Novel application of breath-hold turbo spin-echo T2 MRI for detection of acute myocardial infarction. J Magn Reson Imag 7:9961001

10. GarciaDorado D, Oliveras J, Gili J, Sanz E, PerezVilla F, Barrabes J, Carreras MJ, Solares J, SolerSoler J (1993) Analysis of myocardial oedema by magnetic resonance imaging early after coronary artery occlusion with or without reperfusion. Cardiovasc Res 27:1462-1469

11. Choi SH, Kang JW, Kim ST, Lee, BH, Chun EJ, Schuleri KH, Choi SI, Lim TH (2009) Investigation of T2-weighted signal intensity of infracted myocardium and its correlation with delayed enhancement magnetic resonance imaging in a porcine model with reperfused acute myocardial infarction. Int J Cardiovasc Imaging. doi:10.1007/s10554-0099425-6 